\title{
FIRST CONFIRMED RECORD OF AN ESTABLISHED POPULATION OF SAILFIN MOLLY, POECILIA LATIPINNA (ACTINOPTERYGII: CYPRINODONTIFORMES: POECILIIDAE), IN EUROPE
}

\author{
Nicholas KOUTSIKOS ${ }^{1,2}$, Alcibiades N. ECONOMOU ${ }^{1}$, Leonidas VARDAKAS ${ }^{1 *}$, \\ Dimitrios KOMMATAS ${ }^{1}$, and Stamatis ZOGARIS ${ }^{1}$ \\ ${ }^{1}$ Hellenic Centre of Marine Research, Institute of Marine Biological Resources and Inland Waters, Anavissos, Attica, \\ Greece \\ ${ }^{2}$ Department of Environment, University of the Aegean, Mytilene, Greece
}

\begin{abstract}
Koutsikos N., Economou N.A., Vardakas L., Kommatas D., Zogaris S. 2017. First confirmed record of an established population of sailfin molly, Poecilia latipinna (Actinopterygii: Cyprinodontiformes: Poeciliidae), in Europe. Acta Ichthyol. Piscat. 47 (3): 311-315.

Abstract. The ornamental aquarium trade has been responsible for several introductions of non-indigenous species in freshwater ecosystems. This report confirms the presence of an established non-native molly population in a tectonic, brackish, geothermal lagoon located in Greece (Lake Vouliagmeni near Athens). The Vouliagmeni molly was positively identified as the true sailfin molly, Poecilia latipinna (Lesueur, 1821), using the number of scales around the caudal peduncle as the principal diagnostic character within the sailfin molly species complex. To our knowledge, this is the first documented record of an established sailfin molly population in European waters.
\end{abstract}

Keywords: taxonomic identification, alien species, Greece, Lake Vouliagmeni, colour morphs

The ornamental aquarium trade accounts for a steadily growing number of fish introductions worldwide. Poeciliids, in particular mollies, are popular ornamental aquarium fish being deliberately or accidentally released into the wild under the erroneous assumption that these species are effective for mosquito control (Dill and Cordone 1997, Courtenay and Meffe 1989, Gutiérrez and Reaser 2005). However, some introductions of mollies in natural ecosystems have been blamed for adverse environmental impacts (McKay 1989, Williams et al. 1998).

Within the group of mollies, there are two morphologically and behaviourally distinct species complexes, which represent monophyletic evolutionary lineages: the sailfin mollies of the Poecilia latipinna (Lesueur, 1821) complex and the shortfin mollies of the Poecilia sphenops Valenciennes, 1846 complex (Schartl et al. 1995, Breden et al. 1999, Ptacek and Breden 1998). The distinction between the two molly complexes is based primarily on morphological characters and the mating behaviour of the males (Ptacek 2005, Kozak et al. 2008). The sailfin molly complex, named after the strikingly enlarged dorsal fin of males, contains four sexually dimorphic species: Poecilia latipinna, Poecilia petenensis Günther, 1866, Poecilia velifera (Regan, 1914), and Poecilia latipunctata Meek,
1904 (see Ptacek 2005). The shortfin molly complex contains an assemblage of at least 12 morphologically similar but genetically quite distinct species. Shortfin mollies have a much smaller dorsal fin and do not perform courtship during mating (reviewed by Ptacek 2005).

The taxonomy of mollies is complicated and has undergone various re-classifications (Rosen and Bailey 1963, Miller 1983, Lucinda and Reis 2005). Due to the overlapping morphological characters of molly species (Ptacek and Breden 1998) taxonomic identification of feral molly populations is difficult. Indeed several records of mollies are known to derive from misidentified specimens, such as the Vouliagmeni sailfin molly which was originally identified as Poecilia sphenops (see Chintiroglou et al. 1996). Another possible misidentification concerns a Poecilia species in Kenya which has been assigned to $P$. latipinna and as such it is included in FishBase and other global databases of invasive alien species (Seegers et al. 2003). We suspect that there are further citations of the latter species that represent cases of misidentifications, while on the other hand, we cannot not exclude the possibility that it reflects undetected occurrences due to incorrect identifications. These misidentifications of Poecilia species highlight the importance of taxonomic 
studies when examining the spread and the impact of nonindigenous species.

During the year 2010, fish samplings were conducted at Lake Vouliagmeni $\left(37^{\circ} 48^{\prime} \mathrm{N}, 23^{\circ} 47^{\prime} \mathrm{E}\right.$; Fig. 1), a very small (1.59 ha surface area), geothermically-heated (temperature range: $18-29^{\circ} \mathrm{C}$; mean water temperatures in the centre of the lake: $22.5-24.9^{\circ} \mathrm{C}$ ), brackish (salinity range: $14.5 \%{ }_{0}-27 \%$ ) tectonic lagoon (Guelorget and Perthuisot 1992), located near Athens, Greece, in order to identify a non-native molly population. The lake is richly vegetated and harbours a locally endemic species of sea anemone, Paranemonia vouliagmeniensis (see Doumenc et al. 1987) while two more fish species are present in this lake: Millerigobius macrocephalus (Kolombatović, 1891) and the eel, Anguilla anguilla (Linnaeus, 1758), which is extremely rare (Vanhove et al. 2011).

Fish were sampled with the aid of a fry net $(\mathrm{a} 7 \times 2 \mathrm{~m}$ seine, mesh $2 \mathrm{~mm}$ ) towed manually over a $10 \mathrm{~m}$ distance

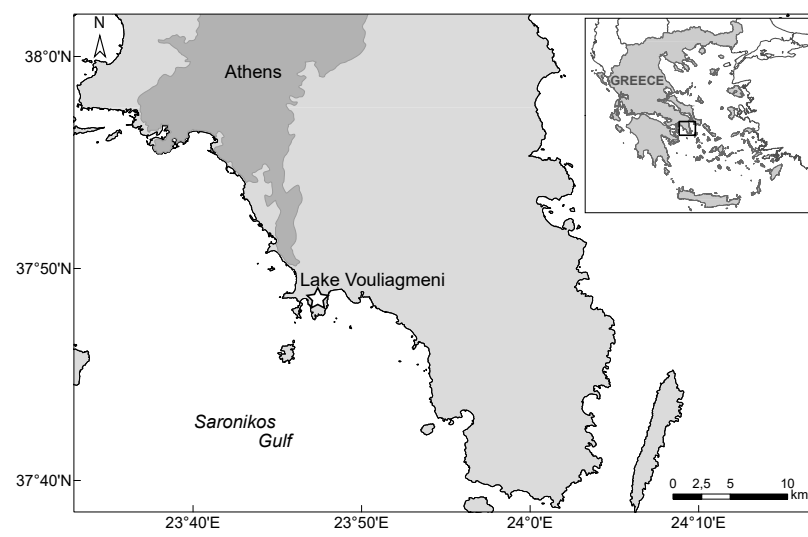

Fig. 1. Map indicating the geographical location of the geothermally heated Lake Vouliagmeni towards the lake shallows (1.0-1.5 m depth). Four hauls were conducted in different parts of the lake and the collected fish were anaesthetized and preserved in a $10 \%$ formalin solution. In the laboratory, all fish were measured (standard length, SL, mm), weighed (total weight, mg), sexed, and their colour variety was recorded. Small males, lacking the elongated dorsal fin that characterises mature males, were distinguished from females based on the presence of a gonopodium. Several morphometric and meristic characters have been used by different authors in taxonomic comparisons among molly species (Sterba 1973, Miller 1983, Snelson 1985, Kittell et al. 2005, Hankison et al. 2006, Hubbs et al. 2008). For the sake of the presently reported study we concentrated on a limited number of characters, namely the number of dorsal fin rays, the number of lateral line scales, and the number of scales around caudal peduncle, proposed previously in order to discriminate between sailfin and shortfin mollies, as well as for species differentiation within the sailfin molly species complex (Table 1).

In all individuals, the number of dorsal fin rays ranged from 13 to 16, which falls well outside the range of counts reported for Poecilia sphenops. Further, our results indicated that the number of lateral line scales was not a character contributing to taxonomic clarifications due to the great overlap in character values among species of the sailfin molly complex. Although the number of dorsal fin rays was a taxonomically more useful character, effectively identifying some individuals as Poecilia latipinna; it was not an "exclusive" diagnostic character, as a proportion of individuals displayed dorsal fin rays counts falling within the range of variation described for all three species. Only the number of scales in the caudal peduncle was a character definitely identifying all individuals as P. latipinna.

Table 1

Diagnostic characters commonly used to identify molly species

\begin{tabular}{|c|c|c|c|c|c|}
\hline Species & $\mathrm{rD}$ & Lls & $\mathrm{Cp}$ & Position of dorsal fin & Reference \\
\hline \multirow{3}{*}{ P. sphenops } & $8-11$ & $25-30$ & \multirow{3}{*}{16 or 18} & $+\mathrm{A}$ & Sterba 1973 \\
\hline & $8-10$ & $>27$ & & \multirow{2}{*}{$-\mathrm{P}$} & Miller 1983 \\
\hline & $8-10$ & $27-30$ & & & Obregón Barboza 1990 \\
\hline \multirow{7}{*}{ P. latipinna } & $13-14$ & $26-28$ & & $++\mathrm{A}$ & Sterba 1973 \\
\hline & $12-16$ & & 16 & \multirow[t]{2}{*}{$+\mathrm{P}$} & Miller 1983 \\
\hline & $12-13$ & & 16 & & Obregón Barboza 1990 \\
\hline & $12-14$ & $25-29$ & & & Hubbs et al. 2008 \\
\hline & $15-16$ & 26 & & & Randall and Hoover 1995 \\
\hline & $15-17$ & & & & Ptacek 2002 \\
\hline & $13-16$ & $26-28$ & 16 & $++\mathrm{A},+\mathrm{P}$ & Presently reported study \\
\hline \multirow{2}{*}{ P. petenensis } & $15-16$ & $28-30$ & \multirow{3}{*}{20} & $+\mathrm{A}$ & Miller 1983 \\
\hline & $12-16$ & $28-29$ & & $+\mathrm{P}$ & Sterba 1973 \\
\hline \multirow{3}{*}{ P. velifera } & 18 & $26-28$ & & $++\mathrm{A}$ & Miller 1983 \\
\hline & $16-19$ & $26-27$ & \multirow[t]{2}{*}{20} & \multirow[t]{2}{*}{$+\mathrm{P}$} & Parzefall 1989 \\
\hline & $17-21$ & & & & Sterba 1973 \\
\hline
\end{tabular}

$\mathrm{rD}=$ number of rays in the dorsal fin; $\mathrm{Lls}=$ number of scales along the lateral line; $\mathrm{Cp}=$ number of scales in the caudal peduncle; $\mathrm{D}=$ dorsal fin, $\mathrm{A}=$ anal fin, $\mathrm{P}=$ pectoral fin; $++\mathrm{A}=\mathrm{D}$ well in front of $\mathrm{A},+\mathrm{A}=\mathrm{D}$ slightly in front of $\mathrm{A},+\mathrm{P}=\mathrm{D}$ in front of $\mathrm{P},-\mathrm{P}=\mathrm{D}$ behind $\mathrm{P}$. 
The Lake Vouliagmeni molly population occurs under several colour varieties that can be grossly grouped into three main morphs: silver-greenish (wild type), black, and black-spotted (Fig. 2). Sexual dimorphism was apparent in all morphs, especially among larger fish. Environmental factors, predominantly ambient temperature, may have an effect on the colour structure of the population. Agnus (1983) has indicated that black spotting in sailfin molly is due to a single allele, and heterozygotes for the mutant allele exhibit variable degrees of penetrance and expressivity, depending on rearing temperature. Progeny developed under warm conditions $\left(28^{\circ} \mathrm{C}\right)$ displayed more normal pigmentation, while progeny raised at $\operatorname{cool}\left(20^{\circ} \mathrm{C}\right)$ temperatures tended to develop melanistic spots. In Lake Vouliagmeni, the mean temperature range $\left(22.5-24.9^{\circ} \mathrm{C}\right)$ falls mainly in the cool side of Agnus (1983) treatments, probably suggesting a shift of expressivity towards black phenotypes.

Large males indicated brighter colouration and a rectangular and considerably longer dorsal fin than females, which is a typical characteristic of many molly species, although females were larger than males, as expected for poeciliid species (Endler 1983). Small males (below $\approx 30 \mathrm{~mm} \mathrm{SL}$ ), by contrast, did not exhibit pronounced colouration and the dorsal fin elongation of large males. In all colour varieties females dominated over males, which is also typical for poeciliid species (Snelson and Wetherington 1980). The percentage contributions of the three morphs were as following: silver-greenish: $53.9 \%$, black: $31.5 \%$, and black spotted: $14.6 \%$. These proportions varied in reverse order to their $\mathrm{M} \div \mathrm{F}$ ratio: silver-greenish: 0.25 , black: 0.33 , and black spotted: 0.53 .
In conclusion, the taxonomic identification of this molly presented acute difficulties stemming from three kinds of problems. First, the presence of melanistic morphs developed through captive breeding, reduced the utility of the natural colouration pattern as a diagnostic character. According to Agnus (1983) black and blackspotted phenotypes do occur occasionally in native populations, but they are very rare. Second, species of the sailfin molly species complex share many morphological similarities that complicate taxonomic comparisons. The character most widely used to discriminate among "sailfin mollies" is the number of dorsal fin rays, but as remarked by Ptacek and Breden (1998), three species (P. latipinna, $P$. velifera, and $P$. petenensis) have overlapping dorsal fin ray counts. And third, these three species are often hybridised by breeders to create new strains for the ornamental trade (Balon 2004, Fosså 2004). These strains may be viable and fertile (Sterba 1973, Ptacek 2002, Balon 2004) and may display confusing patterns of morphological variation. Despite these difficulties, we were able to identify the Vouliagmeni molly as the true sailfin molly, $P$. latipinna, using the number of scales around caudal peduncle as the principal diagnostic character. We presume that this population originated from a domestically-bred melanistic strain of P. latipinna, which was produced for the ornamental aquarium trade through selective breeding. This molly population has proliferated to high-density level, possibly because of favourable environmental conditions and absence of effective competitors and predators. The exact year this strain was introduced in Lake Vouliagmeni is not known,

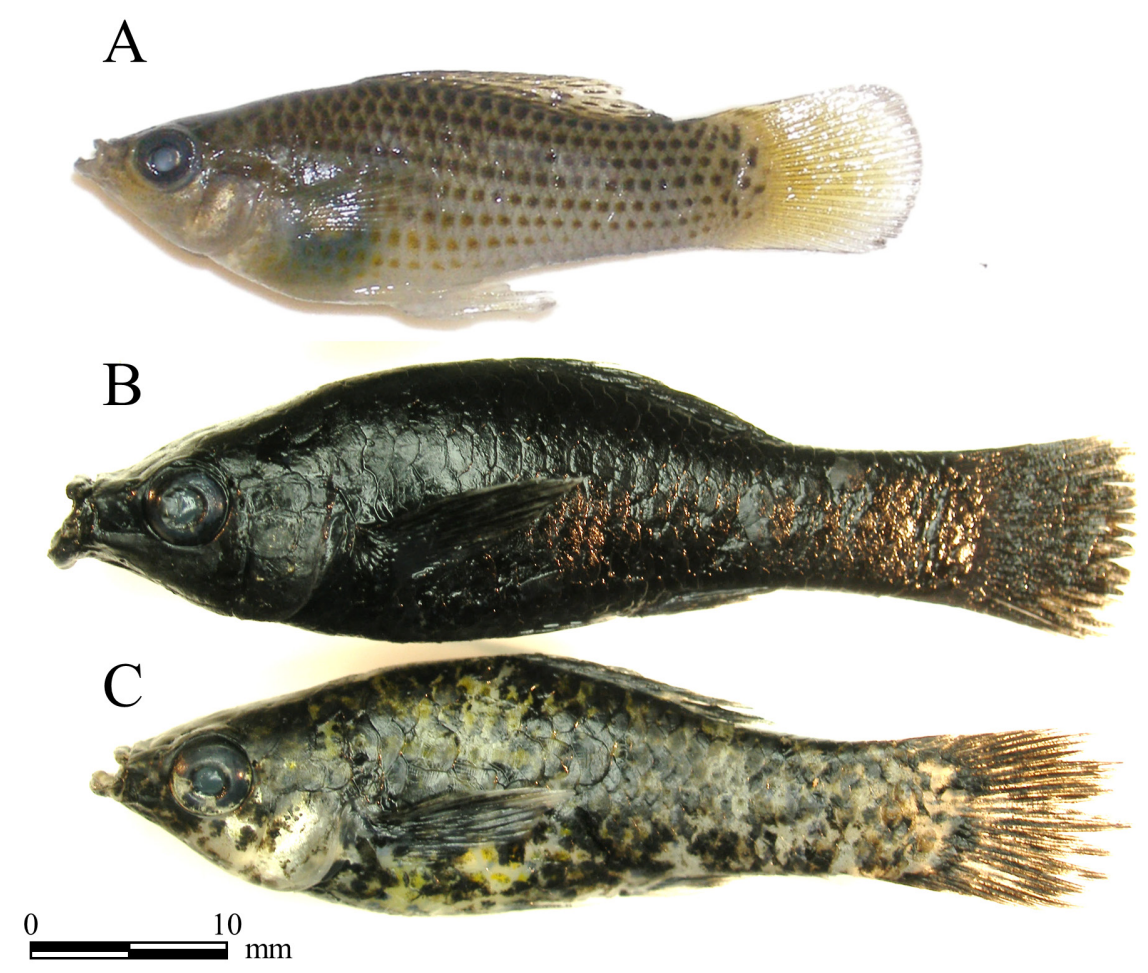

Fig. 2. The three colour morphs of P. latipinna found in Lake Vouliagmeni: male silver-greenish (A) and females black (B) and black-spotted (C) 
but local residents reported that mollies were already present in the lake in the mid-1960s.

This population remains the only known sailfin molly in European waters, which is somehow unexpected on ecological grounds. Despite its reproductive requirement for warm water temperatures, Poecilia latipinna is regarded as a tolerant and adaptable species (Marchetti et al. 2004). Two other commonly traded Poecilia species with broadly similar life histories and environmental tolerances, namely Poecilia reticulata Peters, 1859 and P. sphenops, have a wider, yet localised, distribution in the continent. Therefore, further research is needed in order to seek and explore the reasons for the low occurrence frequency of this species in Europe.

\section{ACKNOWLEDGMENTS}

Many thanks to Mr. Yannis Kapakos for his assistance in the lab.

\section{REFERENCES}

Agnus R.A. 1983. Genetic analysis of melanistic spotting in sailfin mollies. Journal of Heredity 74 (2): 81-84. DOI: 10.1093/oxfordjournals.jhered.a109745

Balon E.K. 2004. About the oldest domesticates among fishes. Journal of Fish Biology 65 (Suppl. 1): 1-27. DOI: $10.1111 /$ j.0022-1112.2004.00563.x

Breden F., Ptacek M.B., Rashed M., Taphorn D., Figueiredo C.A. 1999. Molecular phylogeny of the live-bearing fish genus Poecilia (Cyprinodontiformes: Poeciliidae). Molecular Phylogenetics and Evolution 12 (2): 95-104.

DOI: 10.1006/mpev.1998.0600

Chintiroglou C.-C., Valkouma T., Culley M. 1996. Allometry of feeding and body size in a population of the sea anemone Paranemonia vouliagmeniensis. Journal of the Marine Biological Association of the United Kingdom 76 (3): 603-616. DOI: $10.1017 / \mathrm{S} 0025315400031313$

Courtenay W.R., Meffe G.K. 1989. Small fishes in strange places: A review of introduced poeciliids. Pp. 319-331. In: Meffe G.K., Snelson F.F.jr. (eds.) Ecology and evolution of livebearing fishes (Poeciliidae). Prentice Hall, Englewood Cliffs, NJ, USA.

Dill W.A., Cordone A.J. 1997. History and status of introduced fishes in California. 1871-1996. Fish Bulletin 178.

Doumenc D., England K.W., Chintiroglou C. 1987. A new species of sea-anemone in the genus Paranemonia Carlgren (Anthozoa, Actiniaria) from the Aegean Sea. Zoologica Scripta 16: 271-275.

DOI: $10.1111 /$ j.1463-6409.1987.tb00073.x

Endler J.A. 1983. Natural and sexual selection on color patterns in poeciliid fishes. Environmental Biology of Fishes 9 (2): 173-190. DOI: $10.1007 / \mathrm{BF} 00690861$

Fosså S.A. 2004. Man-made fish: Domesticated fishes and their place in the aquatic trade the hobby. Ornamental Fish International Journal 44: 1-23.
Guelorget O., Perthuisot J.P. 1992. Paralic ecosystems: Biological organization and functioning. Vie et Milieu 42 (2): 215-251.

Gutiérrez A.T., Reaser J.K. 2005. Linkages between development assistance and invasive alien species in freshwater systems of Southeast Asia. USAID Asia and Near East Bureau, Washington, DC, USA.

Hankison S.J., Childress M.J., Schmitter-Soto J.J., Ptacek M.B. 2006. Morphological divergence within and between the Mexican sailfin mollies, Poecilia velifera and Poecilia petenensis. Journal of Fish Biology 68 (5): 1610-1630. DOI: $10.1111 /$ j.0022-1112.2006.001051.x

Hubbs C., Edwards R.J., Garrett G.P. 2008. An annotated checklist of the freshwater fishes of Texas with keys to identification of species. 2nd edn. Texas Academy of Science, Edinburg, TX, USA.

Kittell M.M., Harvey M.N., Contraras Balderas S., Ptacek M.B. 2005. Wild-caught hybrids between sailfin and shortfin mollies (Poeciliidae, Poecilia): morphological and molecular verification. Hidrobiológica 15 (2): 131-137.

Kozak H.L., Cirino L.A., Ptacek M.B. 2008. Female mating preferences for male morphological traits used in species and mate recognition in the Mexican sailfin mollies, Poecilia velifera and Poecilia petenensis. Behavioral Ecology 19 (3): 463-474.

DOI: 10.1093/beheco/arm139

Lucinda P.H.F., Reis R.E. 2005. Systematics of the subfamily Poeciliinae Bonaparte (Cyprinodontiformes: Poeciliidae), with an emphasis on the tribe Cnesterodontini Hubbs. Neotropical Ichthyology 3 (1): $1-60$. DOI: $10.1590 /$ S1679-62252005000100001

Marchetti M.P., Moyle P.B., Levine R. 2004. Invasive species profiling: Exploring the characteristics of non-native fishes across invasion stages in California. Freshwater Biology 49 (5): 646-661. DOI: $10.1111 /$ j.1365-2427.2004.01202.x

McKay R.J. 1989. Exotic and translocated freshwater fishes in Australia. Pp. 21-34. In: De Silva S.S. (ed.) Exotic aquatic organisms in Asia. Proceedings of the Workshop on Introduction of Exotic Aquatic Organisms in Asia. Asian Fisheries Society, Manila, Philippines.

Miller R.R. 1983. Checklist and key to the mollies of Mexico (Pisces, Poeciliidae, Poecilia, Subgenus Mollienesia). Copeia 1983 (3): 817-822.

Obregón Barboza H. 1990. Análisis taxonómico y zoogeográfico de los peces de la zona norte y centro del Estado de Veracruz, México. Tesis de Maestro en Ciencias. Universidad Autónoma de Nuevo León, San Nicolas de la Garza, N.L., México.

Parzefall J. 1989. Sexual and aggressive behaviour in species hybrids of Poecilia mexicana and Poecilia velifera (Pisces, Poeciliidae). Ethology 82 (2): 101115.

DOI: 10.1111/j.1439-0310.1989.tb00491.x 
Ptacek M.B. 2002. Patterns of inheritance of mating signals in interspecific hybrids between sailfin and shortfin mollies (Poeciliidae: Poecilia: Mollienesia). Genetica 116 (2-3): 329-342.

DOI: $10.1023 / \mathrm{A}: 1021201030017$

Ptacek M.B. 2005. Mating signal divergence, sexual selection and species recognition in mollies (Poeciliidae: Poecilia: Mollienesia). Pp. 73-89. In: Grier H.J., Uribe M.C. (eds.) Viviparous fishes. New Life Publications, Homestead, FL, USA.

Ptacek M.B., Breden F. 1998. Phylogenetic relationships among the mollies (Poeciliidae: Poecilia: Mollienesia group) based on mitochondrial DNA sequences. Journal of Fish Biology 53 (Suppl. A): 64-81. DOI: $10.1111 /$ j.1095-8649.1998.tb01018.x

Randall J.E., Hoover J.P. 1995. Costal fishes of Oman. University of Hawaii Press, Honolulu, HI, USA.

Rosen D.E., Bailey R.M. 1963. The poeciliid fishes (Cyprinodontiformes), their structure, zoogeography, and systematics. Bulletin of the American Museum of Natural History 126 (1): 1-176.

Seegers L.L., De Vos L., Okeyo D.O. 2003. Annotated checklist of the freshwater fishes of Kenya (excluding the lacustrine haplochromines from Lake Victoria). Journal of East African Natural History 92 (1): 11-47. DOI: 10.2982/0012-8317(2003)92[11:ACOTFF]2.0.CO;2
Schartl M., Wilde B., Schlupp I., Parzefall J. 1995. Evolutionary origin of a parthenoform, the Amazon molly Poecilia formosa, on the basis of a molecular genealogy. Evolution 49 (5): 827-835.

DOI: $10.1111 / \mathrm{j} .1558-5646.1995 . t b 02319 . x$

Snelson F.F.jr. 1985. Size and morphological variation in males of the Sailfin molly, Poecilia latipinna. Environmental Biology of Fishes 13 (1): 35-47. DOI: $10.1007 / \mathrm{BF} 00004854$

Snelson F.F.jr., Wetherington J.D. 1980. Sex ratio in the sailfin molly, Poecilia latipinna. Evolution 34 (2): 308-319. DOI: $10.1111 /$ j.1558-5646.1980.tb04819.x

Sterba G. 1973. Freshwater fishes of the world. Tropical Fish Hobbyist Publication, Neptune City, NJ, USA.

Vanhove M.P.M., Kovačić M., Koutsikos N.E., Zogaris S., Vardakas L.E., Huyse T., Economou A.N. 2011. First record of a landlocked population of marine Millerigobius macrocephalus (Perciformes: Gobiidae): observations from a unique spring-fed karstic lake (Lake Vouliagmeni, Greece) and phylogenetic positioning. Zoologischer Anzeiger 250 (3): 195-204. DOI: 10.1016/j.jcz.2011.03.002

Williams G.D., Desmond J.S., Zedler J.B. 1998. Extension of 2 nonindigenous fishes. Acanthogobius flavimanus and Poecilia latipinna, into San Diego Bay marsh habitats. California Fish and Game 84 (1): 1-17.

Received: 18 April 2017

Accepted: 11 June 2017 Published electronically: 30 September 2017 